\title{
Health Risks of Newspaper Ink when Used as Food Packaging Material
}

\author{
Swapnali Jadhav ${ }^{1}$ (D), Swaroop S. Sonone ${ }^{1, *(D)}$, Mahipal Singh Sankhla ${ }^{2}$ (D), Rajeev Kumar ${ }^{3 \text { (D) }}$ \\ 1 M.Sc. Forensic Science, Government Institute of Forensic Science, Aurangabad, Maharashtra, India; \\ jadhavswapnali6760@gmail.com (S.J.); sononeswap4@gmail.com (S.S.S.); \\ 2 Research Scholar, Department of Forensic Science, School of Basic and Applied Sciences, Galgotias University, Greater \\ Noida, India; mahipa14n6@gmail.com (M.S.S.); \\ 3 Associate Professor, Department of Forensic Science, School of Basic and Applied Sciences, Galgotias University, Greater \\ Noida, India; rajeev4n6@gmail.com (R.K.); \\ * Correspondence: sononeswap4@ gmail.com;
}

Scopus Author ID 57219960845

Received: 6.12.2020; Revised: 12.01.2021; Accepted: 15.01.2021; Published: 20.01.2021

\begin{abstract}
Newspapers are generally used almost everywhere in our daily lives as newspapers may be the first known packaging materials to carry food to homes and offices. The food contact material needs to be set with the characteristics of suitable products. Preferring appropriate food wrapping material is a difficult problem because of the enormous types of products, food contact, and practices. The ink used for newspaper printing contaminates food after packaging in the newspaper, which can severely impact individual wellness. Contamination of food indicates the appearance of harmful chemical and infectious microorganisms that can influence unfavorable effects on human health. The ink used to print the newspaper consist of components such as Lead, Naphthylamines aromatic hydrocarbon, and AhR (aryl hydrocarbon receptor) agonist that produce various major individual well-being implications such as neurotoxicity, cardiovascular diseases, kidney diseases, various cancer, liver failure, lung damages, weak bones and even death in cases of extremely high contagion.
\end{abstract}

Keywords: newspaper; food; ink; contamination; toxicity; health effect; packaging materials.

(c) 2020 by the authors. This article is an open-access article distributed under the terms and conditions of the Creative Commons Attribution (CC BY) license (https://creativecommons.org/licenses/by/4.0/).

\section{Introduction}

Newspapers are significant sources of information in daily life. Newspaper and/or associated materials have been used in food packaging or are in food contact for several years. Foods are usually wrapped in a newspaper to bring food parcels, mostly used by a street food vendor to pack the food and also used at home to remove the excess oil from deep-fried food. Food packaging is essential to avoid the contamination of food from environmental conditions, but due to minimum costs, newspapers are frequently used to carry the food items. However, the transfer of ink from newspaper to food may affect the quality and safety of food. Eventually, it influences the health of the human being. In India, newspaper commonly uses as packaging materials to wrap, serve, and carry food items. This is a food security threat, particularly regarding street foods or food at other public places such as at a market or fair. People enjoy street foods. Sometimes they spend their time on food safety while eating or about the like quality, whether it made in hygienic conditions or not, but neglect the packaging materials utilized for wrapping or serving. The chances are that the food we take food from street vendors is often wrapped in a newspaper [1]. Food contaminates due to transmission of chemical and 
packaging has been done in close association with food (first packaging). It is known that minimum contamination may occur from second, third, and even fourth packaging also [2]. Few chemical components in printing inks shortly transfer from food packaging material to food while stacking and storage. The chemicals may then migrate into food. Food with Newsprint constituent raises particular fitness regards because it contains various biologically material having severe health implications after prolonged exposure. Naphthylamine and aromatic hydrogen and carbon compounds are significant [3, 4], printing ink shows a toxic effect. In India, there is a practice of using paper to drain the excess oil from foods. When hot and oily foods are packaged in a newspaper, there is a risk of chemicals in ink entering into food products. The close association between the oily food and the newspaper increases the risk of components being transferred through the oil used to cook food lipid act as a means of transmission of ink constituent. Food safety and standards authority of India (FSSAI), established under the Ministry of Health \& Family Welfare, Government of India, has suggested packaging laws that forbid the utilization of newspaper or recovered plastic for packaging and wrapping placing, carrying, or distributing foodstuff. The new rules went into effect on July 1st, 2019. Taking notice of the carcinogenic impact of newsprint ink and colors, these laws prevent the application of newspapers and dangerous material for packaging food articles and include particular Indian rules for printing inks for practice on foodstuff packages. While expressing concerns about the security of loose wrapping materials, rules state that materials made of reprocessed plastic, involving carry bags should not be used for food packaging, storage, and transporting or distributing food articles $[4,5]$.

\section{Contamination of Food with Newsprint}

Foodstuff packing connections can be well-defined as an interaction among foods, packaging, and the setting that manufactures an impact on the packaging and/or foods. The main aim of food-packing is shielding the foodstuffs from ecological agents. However, such relations can also prime to a decrease in superiority, security, or both [6]. Reusable news-papers utilized in food-packing resources often lead to the relocation of mineral oil into foods at stages that are intolerable according to current toxicological evaluations [7]. However, still, in many places newspapers used to wrap the food material. The adulteration of foods is a chief issue not just for emerging nations but also for the complete globe who has adapted vending prepared and ready to eat foods at sites like bicycle, carts, streets, semi-mobile carts having no cover, especially near the dirt and trash of jam-packed towns, railroad track, bus depots, school buildings, Dhabas as well as fast-food street sellers. Approximately in India, more than 3 million individuals are unswervingly entangled in roadside food businesses. Roadside foods offer an income for lakhs of persons in a country with reasonable values to the middle-income \& lower-income classes [8]. Not a single food-packing material is entirely inert that's why it is likely for their biochemical elements to travel into the packaged foods. Ceramics, metal, rubber, glass, plastics, and paper can release tiny quantities of their biochemical elements when they contact particular kinds of food products. Such release of elements to the foods is identified as migration. Migration of substances from packing things into the foods relies on the conformation of the packing source, degree of interaction, nature of the foodstuff, period of contact, the temperature of food, and chemicals' ability to move in the packaging [9]. Packing organizations and other food contact resources are also a foundation of substances in food products and drinks. Anthropological contact with packing compounds and other 
ingredients with foods may result in infections due to migration from the packaging materials into foodstuffs. The intensity and danger of the chemical migrants depend on their quantity and characteristics (Maria and Timothy, 2010), duration of contact, and exposure temperature, with the high ranges observed where there was a straight contact amongst the food and packing material and where the prior had a high-fat content on the contact-surface [10,11]. The ability of foods to interrelate with their packing is an important feature that can affect superiority, nature, and shelf-life. Adherence of residues to the wrapping may produce satisfactoriness, intensify oxidation and off-flavors, amplify waste, and decrease the product superiority.

\subsection{Factors that change the quantity and proportion of migration.}

a. Indirect or Direct exposure of food with the packing material.

b. Features of the material in interacting with foods like permeability, width of plastics etc.

c. Characteristics of mobile substances such as molecular size, vapor pressure, structure, polarity, etc.

d. Amount of initial Migrant substances in the packing material.

e. Exposure duration and atmospheric temperature.

f. Ingredients of food-packing material $[12,13]$.

In the past few years, foods have been adulterated with Benzophenone and Isopropylthioxanthone or ITX utilized for news-paper printing purposes. To safeguard that any biochemical relocation does not carry a threat to costumer's well-being, suggestions with an exact study on biochemical migration from news-paper to foods are necessary. News-paper comprised approximately $3,000 \mathrm{mg} / \mathrm{kg}$ mineral oil. These mineral oils come into a classification. The Joint FAO/WHO Expert Committee on Food Additives (JECFA) recognized an acceptable daily intake of $0.01 \mathrm{mg} / \mathrm{kg}$ body weight. Utilizing standard expectations for measuring particular migration limits, a maximum acceptable amount in foods of $0.6 \mathrm{mg} / \mathrm{kg}$ is resultant [14]. In current packing, toners and polishes are used to the exterior of packing substances. However, lower molecular mass substances like photoinitiators and plasticizer present in printing inks may infuse over the material and then migrate to foodstuffs [15].

\section{Newspaper Ink: Composition and Its Role}

According to Kirk-Othmer, printing is widely used to pass on the information and decorate objects. This has resulted in printing being used on many differential objects. Special ink has been advanced for use in diverse circumstances.

\subsection{Printing inks are manufactured of 4 basic components.}

a. Pigment - For coloring the ink \& to make it impervious.

b. Resin - For binding the ink into the film to bind it into the printed skin.

c. Solvent - For making ink flow so that it can be shifted to the printing site.

d. Additive - This changes the physical assets of the ink so that it can suit diverse conditions [16].

Various chemicals and ingredients are supplemented to manufacture the newspaper ink. It consists of pigments and dyes that can be inorganic or organic in behavior and other additives such as paraffin or wax to help the newspaper ink dry faster. Mineral oils are usually utilized in ink used in news-paper printings. If food is filled in carton-boards made from reusable fiber, 
then there may be the possibility for them to travel to the foods. Movement of particular ink compositions like photoinitiators and plasticizers from printed food packing material into foods also stated. Various chemicals are utilized in producing news-paper ink, although the important element is particularly the oil of soybean. This is known as the "vehicle" in ink and was earlier generally manufactured with petroleum oil. However, it currently has been manufactured chiefly with soyabean oil. Another ingredient was supplemented to restrict the soybean-based oil ink from being decomposable. However, it is slightly easier to reprocess than petroleumbased ink [17, 18]. News-papers incline to release the odor of ink over a lengthy time. Newspaper inks contain numerous chemical extracts and organic solvents, such as di-isobutyl phthalate, ethanol, dimethyl sulfoxide or DMSO, di-n-butyl phthalate, and propanol. Ink pigments are tiny but considerably adsorptive; they frequently comprise heavy-metals like $\mathrm{Cd}$, $\mathrm{Hg}, \mathrm{Pb}$, and $\mathrm{Cr}$, which are intimidating to health even inhaled over a long duration $[19,20]$. When this newspaper is disposed into the water either by contamination or through waste material, it can result in adulteration of aquaculture and may affect humans through the food chain system [21]. Inside news-papers, the PAHs may originate from the high fillings of mineral oils current in printing inks. Though, not the PAH contented of a product is of significance in terms of customer contact. However, somewhat the PAH fraction being unconfined through relocation or fading during real use. Contact of customers to PAHs can happen by breathing, digestion, and relocation and diffusion into the skin [22, 23]. Newspapers, question papers, and answer scripts are used for food packaging in developing countries. Society of British Printing Ink Manufacturers (1993) reported that heavy metals such as titanium, molybdenum, iron, and chromate are utilized as pigments in printing ink production; titanium oxide is used for pearlescent pigments; manganese and cobalt are used as driers, and aluminum and brass are used in metallic inks. Food wrapped in any of these papers may be likely be defiled by these heavy metals. Heat and the presence of water or oil on the surface of the food will increase the contamination rate. Dermal administration of black newsprint inks produces local toxicity at the application location in mice [24].

\section{Health Effects of Newspaper Ink}

Food-products adulterated by the ink of newspaper put out particular well-being issues. The ink consists of several bioactive materials with recognized negative fitness properties. Aromatic hydrocarbons and Naphthylamine are the chief issues [19, 3]. The ink utilized in the newspaper had been described to originate lung cancer amongst laborers uncovered to ink haze through rotary letterpress technology of newspaper printing as per an experiment done in Manchester, England. The cancer-causing ability of news-paper ink was associated with the solvent excerpts of carbon black, containing polyaromatic hydrocarbons such as benzo(a)pyrene. Benzo(a)pyrene elements get adsorbed on the carbon black particles [25]. Bladder cancer is one more prominent illness related to dye and ink. Maximum illnesses, counting cancers, have numerous etiology agents; though, direct contact to 4-Aminobiphenyl, Benzidine, and Naphthylamine has been recognized as the key risk issue bladder-cancer with this danger actuality relative to the duration of contact [26, 27, 28]. Studies have revealed health worries concerning contact with some other particular ink mixtures. As an illustration, rat bladder cancer is encouraged by 2-Naphthylamine [29]. By the way, contact of arylamines (hairdressers, cigarette smokers, and employees of textile and dye companies) has been related to a particularly greater hazard for bladder cancer in males [30]. Supplemented to the 
aforementioned cancer-causing properties of the printing ink, another study revealed that newspaper ink and newspapers consist of agonists for the AhR. Pathway of AhR is a ligandreliant, basic helix-loop-helix, Per-Arnt-Sim-containing transcription factor that arbitrates a varied collection of biotic and toxicological properties a diversity of animals [19, 31]. Other Proofs show that long-lasting contact to comparatively high amounts of a metabolically labile PAH or polycyclic aromatic hydrocarbon AhR agonist, i.e., $\beta$-Naphthoflavone, can be as useful at generating AhR-reliant deadliness as a solitary contact to persons that are biologically tenacious $[19,32,33]$. Other studies show that when a PAH metabolizes enzymes, such as CYP1A (cytochrome P450, family 1, subfamily A) whichever is chemically reserved or bashed, biologically labile AhR ligands will generate AhR-reliant deadly properties [34, 35]. The research above suggests possible negative fitness properties for susceptible inhabitants with conceded organ functions, such as persons with a weaker immune system, like senior citizens and young ones. Meanwhile, the multifaceted combination of substances from newspaper ink can comprise AhR agonists andCYP1A inhibitors; the contact to such excerpt on a continuing base could direct AhR-reliant deadliness. The well-being threat of ink pollution to foodstuffs and extensive contact with multifaceted elements should always be regarded because of the possibly varied collection of biotic and toxicological properties. Future study is necessary to sustenance severer rules to remove community contact to these strong concealed health risks. Presently, tracing the consequences of long-lasting ecological contact to a track combination of poisons throughout everyday life is tremendously problematic [36]. Benzophenone, Benzidine, Naphthylamine, and 4-Aminobiphenyl found in news-paper and other reusable paper are the chief danger issue for bladder-cancer, with jeopardy being relative to contact levels. Benzophenone had been described as the key endocrine trouble making substances in babies and pregnant women [37].

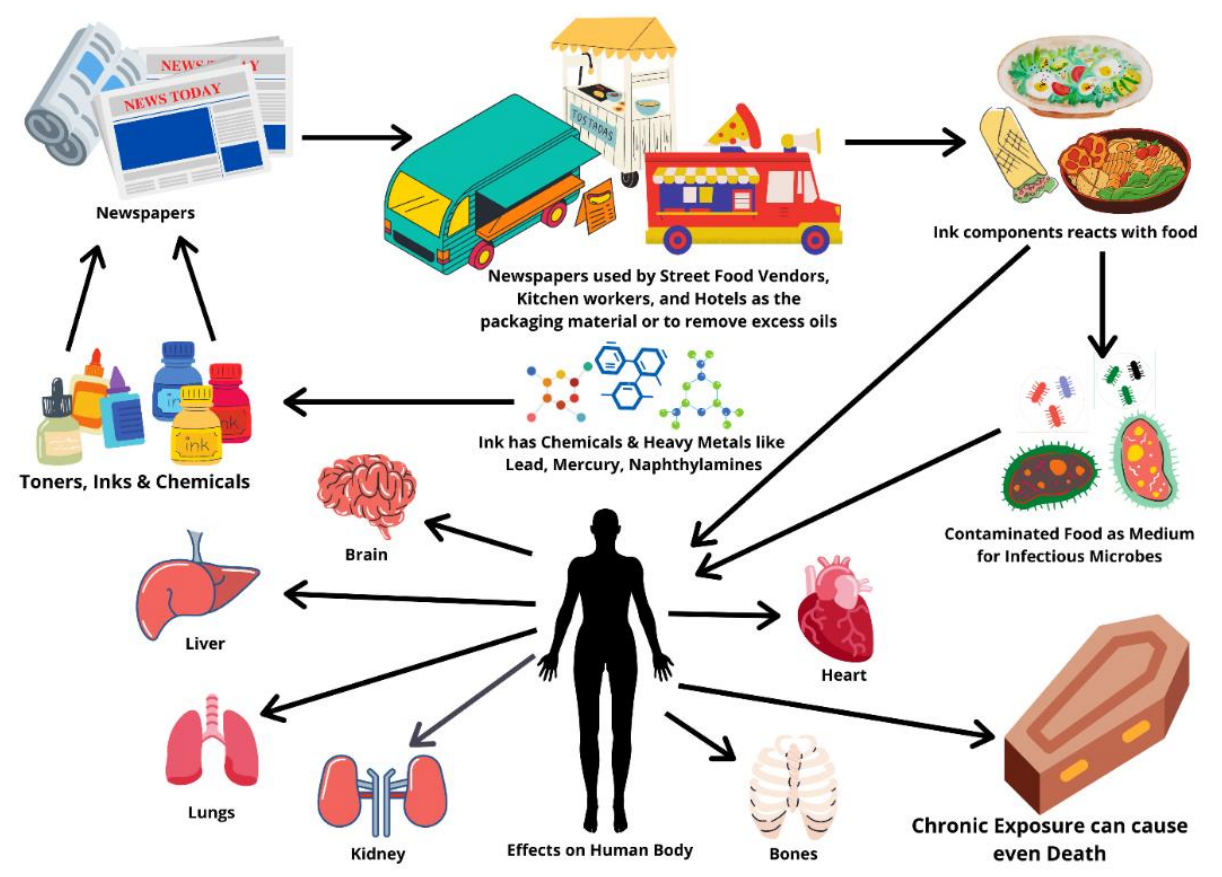

Figure 1. Depiction of Health Hazards of Newspaper Ink.

\section{Alternative Materials for Food Packaging}

Food contact material prevents the foodstuff from any impurity or some other undesirable element that spoils. It makes it inferior or unfit; food packages make it more 
accessible to transportation and store foods, providing a stable quality. It also makes advertising meaningful and makes products more usable and convenient [38]. The chief use of food packing is to guard the produce against the environment. Additional use is to uphold the food's superiority through the 'produce's shelf-life [39]. In today's scenario, there are various materials for the food packaging present in the market. From Stainless steel to Bamboo, there are varied kinds of packaging materials. Day by day, these materials are evolving as an alternative for newspapers for food packaging. As plastic waste endures to be an ecological danger and newspaper being a threat to human health, firms are approaching substitutive packaging materials to battle worldwide issues. Following are some of the alternatives that can be used for packaging foodstuffs.

\subsection{Bamboo.}

It is very important to use biodegradable and biotic material to be used as packaging material. Bamboo is one of the best alternatives to the newspaper and plastic packaging. Bamboo can cultivate much quicker and spread about dual the height of a human in 4 years. It can be made into fibers and thin sheets, which helps make a good alternative for food packaging material [40].

\subsection{Sea wood.}

In the near past, researchers have identified sea wood as an important alternative for food packaging. One of the finest features of sea wood is that it is edible and flexible. This makes it a good option as a packing material. It possesses the quality of naturally degrading in 4 to 6 weeks without making a nuisance in the environment [41-43].

\subsection{Stainless steel.}

Stainless steel has been reported to be the most used alloy, used for cutlery and kitchen purposes. Stainless steel is a common material for food packing in developing nations. The unique characteristic of steel is that it can be modified into varied structures as per customers' need. It is malleable and ductile, making it suitable to be used as containers [44].

\subsection{Polylactic acid (PLA)}

PLA or Polylactic acid is thermoplastic polyester consequent from reusable sources like sugar cane or corn starch. It is biodegradable but may take years to decompose in the natural environment [45].

\subsection{Polyhydroxyalkanoates (PHA).}

PHA or Polyhydroxyalkanoates class of natural and decomposable polymers can decay not just in manufacturing composting apparatus but also in the earth, lake, and salt-water. PHA is formed using a novel methodology, as they are, in usages, the breakdown derivative of cellulosic material by some selected bacteria. Both PHA and PLA are resultant from natural and renewable raw materials [46-48].

\subsection{Cornstarch packaging.}


Cornstarch is biological in nature, which is eco-friendly to the packaging industry. Consequent from the corn or maize, it has plastic-like features that can be utilized in numerous backgrounds that have conventionally depend on plastics. A U.K. based company Corn Ware has made technologically advanced plastic bags and lunch boxes made out of corn for packing usages of food industries [49]. The harmful effect of newspaper and its ink has led to developing new, innovative, and eco-friendly materials as an option for food packaging. The non-degradable nature of plastic has also opened up a new way to find and develop more biodegradable materials [50].

\section{Discussion}

Newspaper is habitually used for wrapping and packaging food items in countless places. It is mostly used as a food packing material in various developing nations. FSSAI or Food Safety and Standard Authority of India suggested some rules regarding the use of newspaper but still, due to least prices, businesspeople, small shops, hotels, restaurants, or even in-houses newspaper used as packaging material. Some people know when newsprint contaminated foodstuff, and we consume such food for a prolonged period, leading to a severe health effect. Newspaper printing ink comprises various bioactive substances, colors, pigments, binders, and additives; such compound migrates from paper to food and newspapers are absorbent enough to soak newsprint, which may cause chronic toxicity. Furthermore, when handled by several people during manufacturing, handling, transportation, it allows bacteria to get stuck between the newspaper pages that showcase the negative effect on individuals' wellbeing after consuming packed food. There is food packaging material available as an alternative to the newspaper. We need to use such biodegradable materials to pack food. The packaging material that is manufactured from eco-friendly matter could be the most suitable alternative solution to the newspaper packaging. Such packaging reduces the health implications of an individual and increases the hygienic environment for food consumption.

\section{Conclusion}

There is some distance between upcoming biodegradable packaging sources and insufficient knowledge regarding newspaper ink's harmful effect. Food companies, street vendors, food regulators, or whoever uses the newspaper for packaging the food need to enhance food safety by using the best packaging material. Do not use newspapers to pack, wrap, or help the food or remove extra oil from deep-fried food. As discussed above, there are numerous hazardous effects of newspaper ink on humans. There is a need to create alertness among food businesses, small hotels, and consumers about the newspaper's harmful effects being dangerous for wrapping food. Raising awareness about its consequences should also be governed by concerned authorities. There is a need to follow FSSAI guidelines regarding food safety. Appropriate measures need to be taken to regulate the practice of newspaper as packing material and the implementation of alternative sources for food packaging.

\section{Funding}

This research received no external funding. 


\section{Acknowledgments}

This review has no acknowledgment.

\section{Conflicts of Interest}

The authors declare no conflict of interest.

\section{References}

1. Paschke, M.; Hutzler, C.; Brinkmann, J.; Henkler, F.; Luch, A. Polycyclic Aromatic Hydrocarbons in Newspaper Inks: Migration, Metabolism, and Genotoxicity in Human Skin. Polycyclic Aromatic Compounds 2015, 35, 32-40, https://doi.org/10.1080/10406638.2014.900643.

2. Ardic, M.; Kahve, H.; Duran, A. Chemical Migration In Food Technology. Academic Journal of Science 2015,04, 163-168.

3. Zhou, R.; Stanley, R. Food risks associated with newspaper ink and contaminated recycled fibre materials. Journal of Hygiene Science 2011, 2, 7-10.

4. Leach, R.H.; Pierce, R.J.; Hickman, E.P.; Mackenzie, M.J.; Smith, H.G. The printing ink manual. Springer 1993, 1 .

5. Charan, B.; Madhumita, G. Assessment of Strengthening the Role of-Food Safety and Standards Authority of India (Fssai) Amidst Burgeoning Online Food Delivery Platforms: New Regulations, Challenges and The Way Forward, Review. Studies in Indian Place Names 2020, 40, 2869-2879.

6. Hotchkiss, J.H. Food-packaging interactions influencing quality and safety. Food Additives \& Contaminants, 1997, 14, 601-607, https://doi.org/10.1080/02652039709374572.

7. Biedermann, M.; Grob, K. Is recycled newspaper suitable for food contact materials? Technical grade mineral oils from printing inks. European Food Research and Technology 2010, 230, 785-796, https://doi.org/10.1007/s00217-010-1223-9.

8. Kulkarni, R.V.; Shirsat, S.D.; Bhadange, D.G. Bacteriological Quality of Street Vended food Panipuri: A Case Study of Amravati City (MS) India. Biosci. Discov. 2011, 2, 350-354.

9. Castle, L. Chemical migration into food: an overview. In: Chemical migration and food contact materials. Woodhead Publishing. 2007; pp. 1-13.

10. de Fátima Poças, M.; Hogg, T. Exposure assessment of chemicals from packaging materials in foods: a review. Trends in Food Science \& Technology 2007, 18, 219-230, https://doi.org/10.1016/j.tifs.2006.12.008.

11. Brown, H.; Williams, J.; Kirwan, M. Packaged product quality and shelf life. Food and beverage packaging technology 2011, 59-84, https://doi.org/10.1002/9781444392180.

12. Meiron, T.S.; Saguy, I.S. Wetting properties of food packaging. Food Research International 2007, 40, 653659, https://doi.org/10.1016/j.foodres.2006.11.010.

13. Altuntas, U.; Yavuz, M.; Yucetepe, A.; Ozcelik, B. Safety of food packaging and toxic substance migration to food. World Food Journal, 2014, 90-97.

14. Boczkowski, P.J.; Mitchelstein, E.; Suenzo, F. The Smells, Sights, and Pleasures of Ink on Paper: The Consumption of Print Newspapers During a Period Marked by Their Crisis. Journalism Studies 2020, 21, 565-581, https://doi.org/10.1080/1461670X.2019.1670092.

15. Greenwo, V. The Migration of Selected Ink Components From Printed Packaging Materials Into Foodstuffs, Proposed activity for year four of the four-year surveillance programme for chemical migrants from food contact materials. UK Food Survey Information Sheet (FSIS) 2011.

16. Suslick, K.S. Kirk-Othmer encyclopedia of chemical technology. J. Wiley \& Sons: New York 1998, 26.

17. Biedermann, M.; Ingenhoff, J.-E.; Zurfluh, M.; Richter, L.; Simat, T.; Harling, A.; Altkofer, W.; Helling, R.; Grob, K. Migration of mineral oil, photoinitiators and plasticisers from recycled paperboard into dry foods: a study under controlled conditions. Food Additives \& Contaminants: Part A 2013, 30, 885-898, https://doi.org/10.1080/19440049.2013.786189.

18. Kanungo, B.; Rohit, K. Unknowingly Accepting Health Hazards In Daily Routine Life A Survey In A Small Town Of Madhya Pradesh. Industrial Engineering Journal 2017.

19. Bohonowych, J.E.S.; Zhao, B.; Timme-Laragy, A.; Jung, D.; Di Giulio, R.T.; Denison, M.S. Newspapers and Newspaper Ink Contain Agonists for the Ah Receptor. Toxicological Sciences 2008, 102, 278-290, https://doi.org/10.1093/toxsci/kfn011.

20. Tarnow, P.; Hutzler, C.; Grabiger, S.; Schön, K.; Tralau, T.; Luch, A. Estrogenic Activity of Mineral Oil Aromatic Hydrocarbons Used in Printing Inks. PLOS ONE 2016, 11, https://doi.org/10.1371/journal.pone.0147239.

21. Sonone, S.; Jadhav, S.; Singh Sankhla, M.; Kumar, R. Water Contamination by Heavy Metals and their Toxic Effect on Aquaculture and Human Health through Food Chain. Letters in Applied NanoBioScience 2020, 10, 2148-2166. 
22. Boffetta, P.; Jourenkova, N.; Gustavsson, P. Cancer risk from occupational and environmental exposure to polycyclic aromatic hydrocarbons. Cancer causes \& control: CCC 1997, 8, 444-472, https://doi.org/10.1023/a:1018465507029.

23. Bosetti, C.; Boffetta, P.; La Vecchia, C. Occupational exposures to polycyclic aromatic hydrocarbons, and respiratory and urinary tract cancers: a quantitative review to 2005. Annals of Oncology 2007, 18, 431-446, https://doi.org/10.1093/annonc/mdl172.

24. Mahler, J.F. NTP Technical Report on Toxicity Studies of Black Newsprint Inks Administered Topically to F344/N Rats and C3H Mice (No. 92). National Toxicology Program, US Department of Health and Human Services, Public Health Service, National Institutes of Health. 1992.

25. Leon, D.A.; Thomas, P.; Hutchings, S. Lung cancer among newspaper printers exposed to ink mist: a study of trade union members in Manchester, England. Occupational and Environmental Medicine 1994, 51, 8794. http://dx.doi.org/10.1136/oem.51.2.87.

26. Hendry, W.F.; Blandy, J.P.; Glashan, R.W.; Hall, R.R.; Wallace, D.M.A.; Baxter, P.J.; Couch, J.A.; Finch, W.M.; Howe, D.W.; Parkes, D.H.G.; Westbrook, M.B. Occupational Bladder Cancer: A Guide for Clinicians: The Baus Subcommiuee On Industrial Bladder Cancer. British Journal of Urology 1988, 61, 183191.

27. Konety, B.R.; Carroll, P.R. Urothelial carcinoma: cancers of the bladder, ureter, \& renal pelvis. Smith's General Urology. 17thed. New York: Mc Graw-Hill Companies 2008, 308-327.

28. Ruder, A.M.; Carreon, T.; Ward, E.M.; Schulte, P.A.; Halperin, W. Bladder Cancer. In: Textbook of clinical occupational and environmental medicine. Rosenstock, L.; Cullen, M.R.; Brodkin, C.A.; Redlich, C.A. (Eds.), 2005; pp. 757.

29. Hicks, R.M.; Wright, R.; Wakefield, J.S.J. The induction of rat bladder cancer by 2-naphthylamine. British Journal of Cancer 1982, 46, 646-661, https://doi.org/10.1038/bjc.1982.250.

30. Al-Zoughool, M.; Succop, P.; Desai, P.; Vietas, J.; Talaska, G. Effect of N-glucuronidation on urinary bladder genotoxicity of 4-aminobiphenyl in male and female mice. Environmental Toxicology and Pharmacology 2006, 22, 153-159, https://doi.org/10.1016/j.etap.2006.02.002.

31. Woods, S.; Farrall, A.; Procko, C.; Whitelaw, M.L. The bHLH/Per-Arnt-Sim transcription factor SIM2 regulates muscle transcript myomesin2 via a novel, non-canonical E-box sequence. Nucleic Acids Res 2008, 36, 3716-3727, https://doi.org/10.1093/nar/gkn247.

32. Grady, A.W.; Fabacher, D.L.; Frame, G.; Steadman, B.L. Morphological Deformities in Brown Bullheads Administered Dietary $\beta$-Naphthoflavone. Journal of aquatic animal health 1992, 4, 7-16.

33. Navas, J. M.; Zanuy, S.; Segner, H.; Carrillo, M. $\beta$-Naphthoflavone alters normal plasma levels of vitellogenin, 17 $\beta$-estradiol and luteinizing hormone in sea bass broodstock. Aquatic toxicology, 2004, 67, 337-345. https://doi.org/10.1016/j.aquatox.2004.01.016.

34. Billiard, S.M.; Timme-Laragy, A.R.; Wassenberg, D.M.; Cockman, C.; Di Giulio, R.T. The Role of the Aryl Hydrocarbon Receptor Pathway in Mediating Synergistic Developmental Toxicity of Polycyclic Aromatic Hydrocarbons to Zebrafish. Toxicological Sciences 2006, 92, 526-536, https://doi.org/10.1093/toxsci/kfl011.

35. Wassenberg Deena, M.; Di Giulio Richard, T. Synergistic Embryotoxicity of Polycyclic Aromatic Hydrocarbon Aryl Hydrocarbon Receptor Agonists with Cytochrome P4501A Inhibitors in Fundulus heteroclitus. Environmental Health Perspectives 2004, 112, 1658-1664, https://doi.org/10.1289/ehp.7168.

36. Zhou, R.X.; Stanley, R.; Le, M. Contamination of food with newspaper ink: An evidence-informed decision making (EIDM) case study of homemade dessert. Environmental Health Review 2012, 55, 63-69, https://doi.org/10.5864/d2012-005.

37. Muncke, J. Endocrine disrupting chemicals and other substances of concern in food contact materials: An updated review of exposure, effect and risk assessment. The Journal of Steroid Biochemistry and Molecular Biology 2011, 127, 118-127, https://doi.org/10.1016/j.jsbmb.2010.10.004.

38. Abdullahi, N. Hazard Chemicals in Some Food Packaging Materials (A Review). Annals. Food Science and Technology 2014, 15, 115-120.

39. Petersen, K.; Væggemose Nielsen, P.; Bertelsen, G.; Lawther, M.; Olsen, M.B.; Nilsson, N.H.; Mortensen, G. Potential of biobased materials for food packaging. Trends in Food Science \& Technology 1999, 10, 5268, https://doi.org/10.1016/S0924-2244(99)00019-9.

40. Hermawan, D.; Lai, T. K.; Jafarzadeh, S.; Gopakumar, D. A.; Hasan, M.; Owolabi, F. T.; Khalil, H. A. Development of seaweed-based bamboo microcrystalline cellulose films intended for sustainable food packaging applications. BioResources 2019, 14, 3389-3410.

41. Rajendran, N.; Puppala, S.; Sneha Raj, M.; Ruth Angeeleena, B.; Rajam, C. Seaweeds can be a new source for bioplastics. Journal of Pharmacy Research 2012, 5, 1476-1479.

42. Liu, L. Bioplastics in food packaging: Innovative technologies for biodegradable packaging. San Jose State University Packaging Engineering 2006, 13, 1348-1368.

43. Marichelvam, M.K.; Jawaid, M.; Asim, M. Corn and rice starch-based bio-plastics as alternative packaging materials. Fibers, 2019, 7, https://doi.org/10.3390/fib7040032.

44. Modiano, P. Invisible Ink: A Novel. World Republic of Letters, 2020. 
45. Song, W.; Yang, M.; Zhao, Y.; Zhu, M.; Zhu, Y.; Ren, H.; Tian, S.; Miao, Z.; Qian, L. Imidazolium functionalized cellulose filter paper derived from waste newspaper and its application in removal of chromium(VI). Reactive and Functional Polymers 2020, https://doi.org/10.1016/j.reactfunctpolym.2020.104776.

46. Ding, H.; He, P.; Yang, J.; Liu, C.; Zhao, H.; Derby, B. Water-based highly conductive graphene inks for fully printed humidity sensors. Journal of Physics D: Applied Physics 2020, 53, https://doi.org/10.1088/1361-6463/aba78a.

47. Wilkins, T. Recycling and recovered paper: Challenges and opportunities in a circular economy. Appita Magazine 2020, 1 .

48. Saini, S.; Chutani, P.; Kumar, P.; Sharma, K.K. Development of an eco-friendly deinking process for the production of bioethanol using diverse hazardous paper wastes. Renewable Energy 2020, 146, 2362-2373, https://doi.org/10.1016/j.renene.2019.08.087.

49. Krishnan, R.; Jones, J.; Helliblau, M. U.S. Patent No. 10,654,303. Washington, DC: U.S. Patent and Trademark Office. 2020.

50. Works, W.; Wong, J.S. Using Crime News Reporting Themes to Predict Image Inclusion in Newspaper

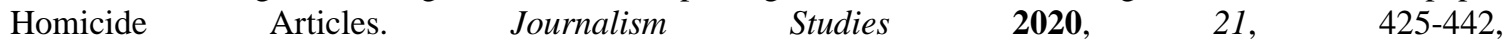
https://doi.org/10.1080/1461670X.2019.1670719. 